\title{
Exploring English Language Teaching in an Ecuadorian Urban Secondary Institution'
}

\section{Explorando la enseñanza del idioma inglés en una institución secundaria urbana ecuatoriana}

\author{
Ximena Burgin and Mayra Daniel ${ }^{2 *}$ \\ Northern Illinois University
}

\begin{abstract}
This article presents a case study focused on the pedagogy of nine English language teachers' pedagogy in Ecuador. The significance of this study is its potential to inform practitioners, teacher educators, and policymakers in countries where teachers need to be prepared to teach in multilingual settings, such as Ecuador. Data analyses of nine observations of practicing teachers seems to suggest the curriculum used to prepare English teachers does not fully meet the educational needs of teachers or students. Observations of secondary level English teachers were conducted using the Classroom Observation Checklist (2010). This instrument is useful to analyze teachers' delivery of content, lesson organization, classroom interactions, verbal and non-verbal communication in the classroom, and integration of media during instruction. One major theme emerged from data analyses; English language teaching appears to follow teaching as a foreign language paradigm. The validation of the results of this exploratory study through the participation of a larger sample size of classroom teachers would be important to provide a more robust conclusion regarding teaching diverse student populations.
\end{abstract}

Key Words: Teacher Preparation, Multilingual Students, Multilingual Educational Context, English Language Teaching

1 Received: June 23, 2016/Accepted: April, 25, 2017

2 xrecald1@niu.edu/mayra.daniel@gmail.com 


\section{Resumen}

Este artículo presenta una investigación exploratoria que examina la pedagogía de nueve maestros de inglés en Ecuador. Este estudio ofrece posibilidades para informar a maestros, profesores, y líderes gubernamentales en países multilingües como Ecuador. Se utilizó la Escala de Observación (2010) para observar a nueve maestros. Este instrumento facilita la observación de la pedagogía en la práctica dividiendo lo observado en cinco categorías: la forma de presentar el contenido de las lecciones, la organización de las lecciones, las interacciones en el aula, la comunicación verbal y no verbal, y el uso de la tecnología como parte integra de la instrucción. El tema principal que emerge del análisis de las observaciones es que la enseñanza del inglés en Ecuador refleja la pedagogía del aprendizaje de un idioma como lengua extranjera. En el futuro, validar los resultados de este estudio exploratorio con un mayor número de participantes sería importante para proporcionar conclusiones más sólidas sobre la enseñanza de estudiantes en Ecuador.

Palabras Clave: Preparación de Maestros, Estudiantes Multilingües, Contextos Educacionales Multilingües, Enseñanza del Inglés

\section{Resumo}

Este artigo apresenta uma pesquisa exploratória que examina a pedagogia de nove mestres de inglês no Equador. Este estudo oferece possibilidades para informar a mestres, professores e líderes governamentais em países multilíngues, como o Equador. Foi utilizada a Escala de Observação (2010) para observar a nove mestres. Este instrumento facilita a observação da pedagogia na prática, dividindo o observado em cinco categorias: a forma de apresentar o conteúdo das lições, a organização das lições, as interações na sala de aula, a comunicação verbal e não verbal, e o uso da tecnologia como parte integral da instrução. $\mathrm{O}$ tema principal que emerge da análise das observações é que o ensino do inglês no Equador reflete a pedagogia da aprendizagem de um idioma como língua estrangeira. No futuro, validar os resultados deste estudo exploratório com um número maior de participantes, seria importante para proporcionar conclusões mais sólidas sobre o ensino de estudantes no Equador.

Palavras Chave: Preparação de Mestres, Estudantes Multilíngues, Contextos Educacionais Multilíngues, Ensino do Inglês, 


\section{Introduction}

This case study of nine English language teachers in Ecuador offers future English language educators insights into effective instructional practices in multilingual and multicultural contexts. In Ecuador, many learners grow up speaking an indigenous tongue at home and in their communities, studying in Spanish at school, and even English since the current curriculum includes its study as an additional language at many levels (Malik, Esaki-Smith, Lee \& Ngan, 2015). Most Ecuadorians might therefore be considered multilingual speakers because, first, they are expected to achieve literacy in the dominant language of their society, Spanish, and many speak the indigenous languages of their communities (Ethnologue, 2016). Indigenous languages merit validation because they provide links to the cultures of the past and knowledge of these facilitate communication in the present. English language teaching (ELT) introduces students to the cultures of the English-speaking world, and is the foreign language of choice in Ecuador. Thus, Ecuadorian language educators face numerous challenges in addressing the different educational needs of the learners in their classes.

Three teacher educators whose work focuses on the preparation of teachers to work with culturally and linguistically diverse students collaborated on the research reported in this article. Two of the researchers are native speakers of Spanish, and all are highly proficient in this language. One researcher was born in Ecuador and completed an undergraduate engineering degree. Another, a native of Cuba, attended elementary school up to the sixth grade in her country. She is a SpanishEnglish-French trilingual speaker. The third investigator completed a master's degree in Mexico. An experienced English language teacher who resides in Ecuador was invited to mediate the collaboration across both countries, Ecuador and the United States (U.S.). She became the main contact who helped organize the logistics to implement the study in Ecuador.

Data gathered in this investigation is relevant for educators in diverse educational environments. This case study impacts practical issues, including the design of teacher preparation programs tailored for educators who work in multilingual communities. Drawing from qualitative data, including teacher observations and open-ended questions, this work aims to uncover what teachers need to gain in teacher preparation programs. Based on findings limited by the context and the number of participants, recommendations are suggested for future research and dialogue focused on identifying what tertiary program curricula is needed to prepare English language educators to work in diverse contexts. 
This study began with an informal conversation related to recent and significant educational reforms occurring in Ecuador, a multilingual context for language teaching and learning. The research team explored the implications of government issued educational reforms on teachers that addressed literacy such as Ecuador's National Plan of Good Living and the Ten Year Education Plan discussed by Van Damme, Aguerrondo, Burgos \& Campos (2013) and Gallegos (2008). They consulted the Organic Bilingual Law Decree 1241/ Reglamento General a la Ley Orgánica de Educación Intercultural Decreto No. 1241 (2012) which guaranteed free public education to all learners through the high school years, including provision of books. They examined federal mandates per Ecuador's constitution (2011), and considered governmental mandates aimed at raising the level of English proficiency for the country's future citizens (Gordon, 2015).

Ecuador's leaders are evidencing a systemic effort to raise the levels of literacy (Organic Law, 2012) and also to add effective models of ELT across the curriculum (Gallegos, 2008). The constitution decreed that "It is the right of every person to engage in inter-personal inter-cultural communications in all dimensions." (Constitución de la República del Ecuador, 2011). Ecuador's Ministry of Education reported that between the years 2010 to 2011, a total of 171, 970 teachers took part in at least one professional development course (Van Damme, Aguerrondo, Burgos \& Campos, 2013). These efforts aimed to improve both teachers' pedagogy and their English language proficiency through professional development offered in Ecuador and at select universities in the U.S. (Ambrecht, 2014). With support from the U.S. Embassy a modified version of the TESOL Standards was developed for the Ecuadorian context (Serrano, et al., 2015) and models of teacher preparation were aligned to the Standards for Preparing Teacher Professionals set forth by the Teachers to Speakers of Other Languages Organization (TESOL) (2009), an international evaluative body for tertiary teacher preparation programs.

The research team discussed the role of multicultural and multilingual factors in the Ecuadorian educational context, both at the tertiary level and at pre-K-12. The overarching goal of this study 110 was to examine the pedagogy being implemented in English language classrooms. In order to begin to explore this objective, we conducted formal observations of nine practicing teachers in classes focused on English instruction. Participating teachers were also asked two openended questions focused on (1) how they adjust their literacy/reading strategy instruction for bilingual students and, (2) what they do to create a welcoming classroom environment that validates the multiculturalism 
of Ecuador's demographic. This study was guided by the following research question: What philosophies of ELT undergird participants' practice?

\section{Literature Review}

\section{Language Diversity in Ecuador}

Considering Ecuador's linguistic and cultural diversity is key to offering an equitable education to all students (Constitución de la República del Ecuador, 2011). Students who come to school with mastery of indigenous languages and are better able to express their thoughts in their home language rather than in Spanish, the dominant language of society, cannot be expected to learn through a tongue they do not know (Daniel \& Burgin, 2016: García \& Wei, 2014; Bialystok, 2011; Grosjean, 2008; Cummins, 1991).

Ecuador 's diversity is evident in its demographic. It is a Latin American nation where many citizens are multilingual speakers of the country's official language, Spanish, and an indigenous language. Chisaguano (2006) documented 13 indigenous languages spoken in Ecuador, the newspaper El Tiempo (2015) identified 14, and Ethnologue (2016), a reliable source of information for world languages, traces 25 individual indigenous languages for the country with 24 in the category of living languages, and 21 categorized as indigenous. These facts require consideration in the schoolhouse.

\section{Rationale for Exploring English Language Education in Ecuador}

Ecuador's leaders espouse visions of equity and multiliteracy for its citizens. The country is engaged in a process to advance its educational system and develop teachers' expertise to serve multilingual populations (Cariola-Huerta, 2015; Constitución de la República de Ecuador 2008, 2011; Cevallos-Estareda \& Bramwell, 2015). Curricular requirements for K-12 students in the year 2015 added English language instruction (Cevallos-Estaredas \& Bramwell, 2015; Malik, Esaki-Smith, Lee \& Ngan, 2015). English is now taught as part of the elementary curriculum at public and private schools; beginning at age 5 (Initial 2nd level) in private schools and in the 8th grade in public school settings (Cevallos-Estarellas \& Bramwell, 2015).

In order to begin to frame ELT in Ecuador it is important to analyze what participating Ecuadorian teachers' instructional paradigms reveal to be their challenges as they plan and deliver English language 
instruction. No one could argue that methodological approaches to ELT delineate and control teachers' instructional methods. Teachers' pedagogical knowledge base and what they were taught is effective practice directly impacts learners' academic achievement. Without a doubt, a consideration of equity and social justice are an integral part of effective ELT (Daniel, 2016a: Freire \& Macedo, 2005: Vygotsky, 1986; Atkinson, 1997).

This study's theoretical framework considers what the professional literature suggests equates to best practice for ELT (Daniel, 2016b; Choi \& Morrison, 2014; Coleman \& Goldenberg, 2010; Brisk, 2008; Hornberger, 2002) while emphasizing the sociocultural context of learning (González, Moll, \& Amanti, 2005). This case study is based on an exploration of the philosophies underlying ELT instructional methods as evidenced in practicing teachers' work in Ecuador. We asked if educators in Ecuador are encouraged to "....adopt a conceptualization of integration of language practices in "...the person of the learner" as they plan instruction that makes it possible for " $\ldots$ bilinguals to enter into a text that is encoded through language practices with which they are not quite familiar,", and "..to truly show what they know.." (Garcia \& Wei, 2014, p. 80).

\section{This Study}

Examining ELT in Ecuador offers an initial glimpse to how current reforms are changing this nation's educational system. Gallegos (2008) proposes that the requirement of English study for learners up to the high school level is a scaffold to economic success and to building a nation where all citizens have equitable access to life -success. Exploring pedagogy in ELT through teacher observations and open ended questions seems an appropriate step to document the effects of reforms aimed at ensuring learners in Ecuador master English.

This research investigates the current study of English as a mandatory part of the curriculum in Ecuador's schools. To date few studies have been conducted solely focused on ELT in Ecuador (Daniel \& Burgin, 2016: Cevallos-Estarellas \& Bramwell, 2015). Serrano, Vizcaíno, Cazco \& Kuhlman (2015) summarized their findings of what composes a key instructional problem in ELT in Ecuador. They stated unequivocally that "the majority of English teachers in Ecuador have neither the language proficiency nor the methodologies to teach English effectively in the schools" (p. 109). This claim is alarming yet reported and it invites Ecuadorian researchers to conduct a deeper analysis of ELT in Ecuador. 


\section{Methodology}

\section{Research Design}

This case study addressed observed components of English language teachers' practice in Ecuador. The overarching question asked What philosophies of English language teaching (ELT) undergird participants' practice? Observations of practicing teachers focused on how English language educators:

1. Consider the multiculturalism and multilingualism in their society in instructional planning?

2. Organize the delivery of their lessons to present content?

3. Encourage the direction of student to student and student to teacher classroom interactions?

4. Address verbal and non-verbal communication in the classroom context?

5. Incorporate current technologies in classroom instruction and student tasks?

\section{Context/Participants}

The study was performed in a secondary level public institution located in a northern province of Ecuador. Observations of nine practicing teachers were conducted with each participant observed once for 90 minutes. Participant volunteers were invited to participate by the Ecuadorian educator who served as the mediator for this research. Participants received a consent form indicating that the purpose of the project was to observe classroom teachers and to interview them using open-ended questions focused on factors related to instruction of linguistically and culturally diverse learners (monolinguals and multilingual). Six participants were females and three were males. All nine teachers were mestizo. In addition, participants' teaching experience varied from four to 28 years.

\section{Data Collection Instruments}

This study utilized a classroom checklist to observe teachers' practices and two open-ended questions to explore the level of multicultural understanding among the participants. The Classroom Observation Checklist, originally written in English (Appendix 1) (Center for Educational Innovation, 2010) was modified and translated 
to Spanish (Appendix 2). After the translation, two additional Spanish teachers reviewed the instrument to ensure that the constructs, language, and scale were applicable to the Ecuadorian context. The instrument included five categories with a total of 39 items. These are: (1) Content - seven items, (2) organization - eight items, (3) interaction - seven items, (4) verbal/non-verbal - 12 items, and (5) use of media - five items. Each item was evaluated based on a five-point Likert scale (1 $=$ very poor, $2=$ weak, $3=$ average, $4=$ good, $5=$ excellent, $\mathrm{NA}=$ not applicable). In addition, participants were asked the following two open-ended questions: Do you adjust your reading strategy instruction/ interventions for bilingual students? and, do you strive to create a multicultural classroom environment?

\section{Data Analysis and Interpretation}

Mean, median and frequencies were calculated for each item and by each category of the observation scale (see Appendix 3). The two open-ended questions were analyzed individually to determine if there were patterns among the participants' responses or practices. In addition, the questions were analyzed to decide if the participants' practices compared to current practices and strategies recommended by the professional literature.

\section{Results}

Participant responses to two open-ended questions provided a beginning scaffold to understanding ELT within a multilingual context and to identify recurrent themes in teachers' comments. We follow our analysis of the open ended responses with analyses of data gathered in the quantitative analyses of observations conducted using the Classroom Observation Checklist. Data analyses of the observations and openended questions from nine participants yielded data that served to paint a picture of ELT at the secondary level in one Ecuadorian institution and to analyze what the impact of systemic governmental movements and expenditures have been up to this moment in time as acknowledged by the Instituto Nacional de Evaluación Educativa (2016).

\section{Open Ended Interview Questions}

In this section we discuss findings after examination of responses to the following two open-ended questions asked of the nine participants observed. 
1. In what ways, do you adjust your instruction/ strategies for instruction/interventions for bilingual students?

2. How do you strive to create a multicultural classroom?

\section{Adjusting English Instruction for Bilingual Students}

An open-ended question asked the nine participants to share how they modify instruction for bilingual students. Four participants indicated that they do not adjust their instruction for bilingual students. Out of these four participants, two did not share any information about bilingualism affecting learning. The other two participants indicated that adjusting instruction was necessary. One of them stated that "it is not necessary [to adjust instruction] because our institution is not bilingual." In addition, one participant commented that students are not interested in learning only interested in being promoted to the next level. The other participant mentioned that "learning is not impacted [by bilingualism] because students are used to the influence of both languages so students apply them based on their needs."

It appears that the participants may not share a common definition of what it means to be a bilingual student or what it takes to reach biliteracy. We wonder if biculturalism is a consideration for Ecuadorian teachers or if perhaps the greater focus is on teaching following EFL models and the cultural and contextual nuances are not a consideration. While some of the teachers stated they adjust instructional strategies/ interventions for bilingual students in their instruction, the definition they hold of multiculturalism and multilingualism represented by students' understanding of other cultures and languages is unclear. Ecuador is a multilingual nation and one would expect teachers to note this diversity within their student demographic and instructional planning. It is a concern that two of nine teachers shared that they do not adjust the reading strategies they teach nor their implemented instructional interventions for bilingual students, because they do not consider their institutions to be bilingual.

\section{Creating a Multicultural Classroom}

Conversations related to the second open-ended question are significant for this case study because six participants did not answer the question and the three teachers who provided responses indicated they make efforts to create a multicultural environment in their own classrooms. One participant stated that "a multicultural classroom 
involves learning about the ideas of great authors that express political, cultural and learning in Latin-American and European societies." Another participant indicated that a multicultural classroom is created when "the student uses known vocabulary in home language and then use those words in the language he/she is learning." A third teacher emphasized that a multicultural classroom can be created when "a needs assessment is performed to diagnose multiculturalism and then the teacher adapts instruction based on the students' needs." Based on the data collected, we interpret that the participants' responses suggest that not enough attention is given to this in programs of teacher preparation and/or in professional development. Participants' responses document that their exposure to multiculturalism occurs from studying international literature, subsequent interpretation of ideas in the home language, and through translation of materials from Spanish to English. Although according to the Ministry of Education (2017) a total of 15 million hours of professional development were given to teachers between 2014 to 2016, participants in this study did not indicate that professional development about multiculturalism occurred. Thus, it would be beneficial to conduct further research with a larger sample to corroborate these findings.

\section{Analyses of Data Using the Observation Scale}

In this section, we interpret the data gathered using the categories in the Classroom Observation Checklist (Center for Educational Innovation, 2010); manner of presenting content, lesson organization, media use (technology infusion), classroom interactions (leadership roles), and verbal/non-verbal communication. We use mean, median and frequencies to develop the story of ELT in the context of this case study. We address three recurrent themes using the foci of the categories of the Observation Scale:

1. ELT in Practice

2. Leadership Roles

3. Components not Present in Lessons

\section{ELT in Practice}

The focus of lessons was English instruction centered on the language devoid of a focus on contextual factors. Learners' cultural capital and an awareness and consideration of how this facilitates higher levels of comprehension was not observed. Six of the teachers 
read a book in class to their students focused on the objectives of the lesson, asked the learners to repeat some words and responded to questions. Although three teachers stated they adjust instruction to learners' cultural background, and this suggests there is an awareness of constructivist perspectives that places teachers and students in the role of collaborators, observational data does not provide evidence of this in practice. The teachers gave students definitions of the meaning of unknown words and did not appear to consider how meaning making could occur during the process of interpreting text. Evidence of the philosophy that students will achieve greater comprehension of text when reading the word and the world (Freire \& Macedo, 2005) was not observed. Data indicate professional development has not addressed the possibility of teachers and students functioning as co-learners in the classroom.

\section{Components of Teachers' Lessons and Organization}

In our observations, we hoped to establish if the organization and presentation of lessons reflected selection of lesson topics that were "relevant, culturally comprehensible, reflective of the learners' realities, and not offensive (Daniel, 2016b, p. 32). If evident, this would provide evidence that the backgrounds of multilinguals learners are a consideration. Three of the nine teachers observed incorporated materials in their lessons aimed at helping students with a multilingual/ multicultural background gain access to lesson topics.

We documented many positives in teachers' instructional design and their efforts to organize and deliver lessons. The teachers observed transitioned effectively from one activity to another, began lessons with a clear intent to capture students' attention, and demonstrated an ongoing concern that their efforts needed to lead students to understand. Their lessons evidenced their ability to scaffold instruction (even if this did not consider learners' cultural capital), and the ways they summarized their daily lessons at the end of the day addressed what they had covered as they linked the day's work to past and future lessons. During lessons the teachers effectively held the students' attention even when curricular materials were not selected keeping in mind students' cultural capital. The questions that remain relate to whether or not teachers' expertise has been tweaked to address ELT, and if teachers' professional development has been adequate given the priority that it should receive.

Observations related to lesson delivery document that the teachers implemented skills based English instruction. They used appropriate 
body movements to illustrate content, made good eye contact with their students, and modeled English well because they spoke the language in a comprehensible manner and did so at an appropriate rate of speech. In contrast to these positives, only four of the teachers appeared aware that language and verbal cues are an important factor in cross/linguistic communication in the classroom. We ask if only instructional components related to ELT have been incorporated in teacher preparation. Social justice in ELT was not a focus in lesson planning. The power that English holds in the world as well as the need to validate indigenous languages was not a part of classroom conversations. Pedagogy that would promote greater economic success for all students, including its indigenous, was not a focus in the teachers' pedagogy.

\section{Leadership Roles in the Classroom}

Classroom interactions between the teachers and students were teacher directed. Teachers asked questions and students answered. Teacher led instruction included asking students to share examples written in English and responding to their questions in order to clarify concepts. The teachers engaged in an ongoing evaluation of students' comprehension and did not deviate from what appeared to be their lesson plans for the day. Teachers were the instructional leader whose word was not questioned by the students. This may have been because classroom activities were limited to questions and answers and/or because teachers may have been teaching exactly as they were taught prior to the mandates of the 2008 constitution (Constitución de la República del Ecuador, 2011

\section{Components Missing in Lessons}

The mean, median and frequency values revealed what was present and what was noteworthy due to its absence in ELT in Ecuador. In this section, we present data from the Classroom Observation Checklist in an interpretation of teachers' use of current technologies.

\section{Current Technologies}

It was evident that governmental investments had resulted in the availability of the current technologies in the classrooms. Four teachers were observed to use a computer and a projector. No students were assigned tasks that involved using computers. 


\section{Conclusions and the Future}

This exploratory case study addressed how nine English language teachers in Ecuador address their society's multilingualism and multiculturalism in their instruction. Ecuador's 2008 and 2011 Constitutions proposed far reaching modifications were needed to ensure education was equitably offered to all of its citizens; from young ages to students at the university level (Constitución de la República del Ecuador, 2011). In this article, we also considered if changes in teacher preparation programs, such as requiring teacher candidates to complete clinical hours, was evidenced in the teachers' instruction.

Themes documented in this investigation highlight that practicing teachers need ongoing professional development that will allow them to pass the baton of leadership to their students. We viewed much teacher led instruction with few opportunities for the students to take on the role of leader. We noted the absence of opportunities for students to engage in debates or to present their ideas as most instruction reflected a question and answer format. The teachers welcomed student questions but they were the sole providers of the answers.

Implementing critical thinking paradigms will require teachers to incorporate more dyadic and small group work in their classroom. This will change the schoolhouse completely because it will introduce the possibility that students, and not just the teacher, will have answers. This research suggests that more time is needed for changed paradigms of instruction to become the norm but that changes have begun. These will support governmental efforts to empower all learners.

Helping future Ecuadorian teachers to critically analyze text as they teach English would empower them and provide a medium for them to voice their ideas. We noted transmission models of education rather than proactive models of advocacy. Students are encouraged to ask the teachers questions to clarify their understandings rather than to state and justify their point of view. No observations revealed a focus on empowerment in the pedagogy of the nine observed teachers.

This case study data suggests this study's participants are open to widening their knowledge to the education needs of multicultural/ multilingual students. There appears to be a push for constructivist perspectives in the Ecuadorian schoolhouse but more work is needed to help the teachers achieve this goal. Teachers need time to explore how to address constitutional mandates and incorporate a thoughtful focus on multicultural communications in the classroom. Nevertheless, it is encouraging that professional development is taking teachers in new directions and, in some instances has been guided by a modified 
version of the TESOL Standards developed for the Ecuadorian context (Serrano, et al., 2015).

Observations of teachers suggest ELT incorporates classroom tasks such as games, dialogues, group work, and experiential activities based on everyday events. While students are required to memorize songs, translate narratives, and then discuss what they read in English, curricular design does not reflect a teaching philosophy that recognizes the society's language and cultural diversity. Teachers want to begin this process but have not been taught how to more deeply examine the societal context in learning.

This research supports teachers' need for professional development that addresses their English language proficiency and asks them to implement learner-centered pedagogy (Serrano, Vizcaíno, Cazco \& Kuhlman, 2015). Once teachers engage in ongoing models of professional development, it will be essential to collect data to analyze how they experiment and implement revised instructional paradigms. Evaluation of students' outcome data will provide a better understanding of the effectiveness of the interventions implemented. It is important to recognize that the processes of changing educational paradigms is painstaking and a long-term endeavor which requires learning, exploration, and reflection.

At this juncture, we wish to ask a few questions of Ecuador's educational leaders. Given the massive government funding to improve the schoolhouse, do they note sufficient changes? We were privy to both positive and negative thoughts and perceptions on the part of educators. A teacher commented that "Government expenditures have improved the infrastructure in schools. Now schools have enough space for students and the number of students per classroom is restricted." Teachers' comments merit being part of a larger conversation with educational leaders.

It is important that teachers know how to improve their pedagogy not only by implementing tools and strategies to address the subject matter, but also using data they themselves gather to draw conclusions that will lead them to develop new instructional 120 approaches. We propose Ecuadorian teachers could participate in professional development that places them in the driver's seat and makes it possible for them to follow educational mandates that validate teachers' significant role in student academic achievement. We note some possible areas for improvement in the Ecuadorian school system that would be effectively addressed if professional development were improved and perhaps guided by more teacher input. We interpret the 
following observations as challenges. First, student examination results are being interpreted to reflect teacher competency when examinations are most likely not designed for assessment of teachers. Secondly, teachers may be evaluated for their knowledge of state mandated curriculum and not necessarily on their teaching practices. Lastly, teachers are afraid to lose their jobs if they do not do well on their evaluations. We want to encourage educational leaders in Ecuador to keep in mind that "Learning is enhanced when teachers prepare learners to critically analyze their world. Problem-solving pedagogy welcomes learners to co-design new ways of interacting in communities (Daniel, 2016, p. 34)."

\section{Acknowledgements}

Our appreciation to Dr. Chris Liska Carger for her contribution to this project. Our thanks to the Ecuadorian teachers who participated in this study and to the administrators who facilitated these research efforts. 


\section{References}

Ambrecht, J. (2014). Reforms for education in Ecuador. Quito, Ecuador: Borgen Magazine. Retrieved from http://www.borgenmagazine. com/reforms-education-ecuador/

Atkinson, D. (1997). A critical approach to critical thinking in TESOL. TESOL Quarterly, 31(1), 71-95.

Bialystok, E., Craik, F. I., Green, D. W., \& Gollan, T. H. (2009). Bilingual minds. Psychological Science in the Public Interest, 10, 89-129.

Brisk, M.E. (2008). Language, culture, and community in teacher education. Mahwah, N.J.: Lawrence Erlbaum Associates (for the American Association of Colleges for Teacher Education).

Cariola-Huerta, L. (2015). PISA for development, capacity building plan: Ecuador. Paris, France: Organization for Economic Cooperation and Development

Center for Educational Innovation. (2010). Classroom observation checklist. Minneapolis-St. Paul, Mn: University of Minnesota.

Cevallos-Estarellas, P. \& Bramwell, D. (2015). Ecuador, 2007-2014: Attempting a radical educational transformation. In S. Schwartzman (Ed.). Education in South America (pp. 329-361). London: Bloomsbury Academic.

Chisaguano, S.M. (2006). La población indígena del Ecuador: Análisis de estadísticas socio-demográficas. Retrieved from http://www. acnur.org/t3/fileadmin/Documentos/Publicaciones/2009/7015. pdf?view $=1$

Choi, D. S. \& Morrison, P. (2014). Learning to get it right: Understanding change processes in professional development for teachers of English learners. Professional Development in Education, 40(3), 416-435.

Coleman, R., \& Goldenberg, C. (2010). What Does Research Say about Effective Practices for English Learners? Part IV: Models for Schools and Districts. Kappa Delta Pi Record, 46(4), 156-163.

122 Constitución de la República del Ecuador 2008 (2011). Registro Oficial 449. Retrieved from http://www.oas.org/juridico/PDFs/mesicic4 ecu_const.pdf

Cummins, J. (1991). Language development and academic learning. In L. Malave \& G. Duquette (Eds.), Language, culture, and cognition, (pp. 161-175). Clevedon: Multilingual Matters. 
Daniel, M. (2016, a). Critical pedagogy's power in English language teaching. In L. R. Jacobs \& C. Hastings (Eds.), The importance of social justice in English language teaching (pp. 25-38). Alexandria, VA: TESOL Press.

Daniel, M. (2016, b). Planning instruction for English language learners: Strategies teachers need to know. In D. Schwarzer, \& J. Grinberg (Eds.). Successful teaching:What every novice teacher needs to know (pp. 89-106). Lanham, MD: Rowman \& Littlefield.

Daniel, M. \& Burgin, X. (2016). English language teaching in Ecuador: Teacher preparation, progress and challenges of professional development. Paper presented at the TESOL International Convention and English Language Expo. Baltimore, MD.

Ethnologue (2016). Languages of the world. Retrieved from https:// www.ethnologue.com/country/EC.

Freire, P., \& Macedo, D. (2005). Literacy: Reading the word and the world. London, England: Taylor and Francis.

García, O., \& Wei, L. (2014). Translanguaging: Language, bilingualism, and education. New York, NY: Palgrave MacMillan.

González, N., Moll, L., \& Amanti, C. (Eds.) (2005). Funds of knowledge for teaching in Latino households. Mahwah, NJ: Lawrence Erlbaum Associates, Publishers.

Grosjean, F. (2008). Studying bilinguals New York, NY: Oxford University Press.

Gallegos, R. R. (2008). Igualmente pobres, desigualmente ricos. In R. R. Gallegos (Ed.), Igualmente pobres, desigualmente ricos (pp. 150220). Quito: Ariel-PNUD.

Gordon, A. (2015). Latinoamericanos tienen bajo nivel de inglés y Ecuador no es la excepción. Diario El Comercio. Retrieved from www.elcomercio.com/tendencias/ecuador-niveldeingleslatinoamerica-idiomaseducacion.html

Hornberger, N. H. (2002). Multilingual language policies and the continua of biliteracy: An ecological approach. Language Policy, 1(1), 27-51.

Instituto de Evaluación Educativa (2016). Resultados educativos, retos hacia la excelencia. Retrieved from http:/www.evaluacion. gob.ec/wp-content/uploads/downloads/2016/12/CIE ResultadosEducativos-RetosExcelencia201611301.pdf 
Malik, Z., Esaki-Smith, A., Lee, T., \& Ngan, B. (2015). English in Ecuador: An examination of policy, perceptions, and influencing factors. England: British Council.

Ministerio de Educación (April 20,2017). Expertos educativos analizan los programas de formación docente. Retrieved from https:// educacion.gob.ec/expertos-educativos-analizan-los-programas-deformacion-docente/

Reglamento General a la Ley Orgánica de Educación Intercultural Decreto No. 1241 (2012). Educación de Calidad. Retrieved from http://educaciondecalidad.ec/ley-educacion-intercultural-menu/ reglamento-loei-texto.html

El tiempo (2015, November 23). En el Ecuador se hablan 14 lenguas ancestrales. Retrieved from http://www.eltiempo.com.ec/noticias/ ecuador/4/363211/en-el-ecuador-se-hablan-14-lenguas-ancestrales

Resultados Pruebas Censales. (2008). Retrieved from http:// educacion.gob.ec/wp-content/uploads/downloads/2012/08/ resultadoPruebasWEB.pdf

Serrano, M. E.,Vizcaíno, C. G., Cazco, D., \& Kuhlman, N. A. (2015). Un modelo para restructurar la formación de profesores de inglés en Ecuador. GIST Education and Learning Research Journal, 11(2), 103-117.

TESOL/NCATE Teacher Standards Committee. (2009). Standards for the recognition of initial TESOL programs in P-12 ESL teacher education (2010). Alexandria, VA.: Teachers of English for Speakers of Other Languages. Retrieved from http://www.tesol.org

Van Damme, W., Aguerrondo, I., Burgos, C. C., \& Campos, M. R. (2013). A story of change: How Ecuador seeks to sustain its development agenda through large scale educational reform. Paper presented at UKFIET International Conference on Education and Development - Education and Development post 2015: Reflecting, Reviewing, Re-visioning. Oxford, England.

124 Press.

Vygotsky, L. S. (1986). Thought and Language. Cambridge, MA: MIT 


\section{Authors}

*Ximena D. Burgin holds an Ed.D in Instructional Technology and an MS in Educational Research and Evaluation from Northern Illinois University. Her research interests relate to the implementation of research-based methodologies in the classroom to improve students' academic outcomes. She has developed and evaluated a variety of state and federal programs in K-12 education and adult education, leading her to understand the impact of diverse interventions on academic achievement through the employment of different methodological techniques. She has also taught graduate research classes and she has mentored doctoral students throughout the dissertation process to completion.

*Mayra C. Daniel, Professor at Northern Illinois University in De Kalb, IL, US, is the Bilingual Coordinator for the College of Education. Her work centers on preparing teachers to empower culturally diverse students and their families. She experienced second language acquisition by immersion because at age 10 she and her family fled Cuba to escape communism. Her parents left their homeland with little money but armed with the benefits that an education provides. Her research reflects her belief that all students must receive appropriate instruction to master English in classroom environments that embrace and applaud cultural difference. 


\section{Appendix 1}

\section{Observaciones}

Fecha de la observación:

Grado: Materia:

Género: $\square$ M $\square$ F $\quad$ Experiencia en la docencia: años

\section{SECCIÓN I}

\section{Observación del docente de aula}

Escala de clasificación

$(1=$ muy pobre, $2=$ débil, $3=$ promedio, $4=$ buena, $5=$ excelente, $\mathrm{NA}=$ no aplicable)

\section{CONTENIDO}

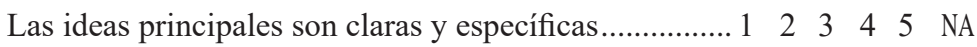

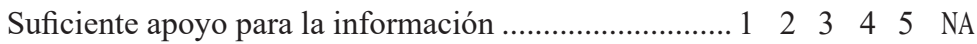

Ideas relevantes fueron claras ....................................... $1 \begin{array}{lllllll}1 & 2 & 3 & 4 & 5 & \mathrm{NA}\end{array}$

Pensamiento critico o de orden superior era necesar..... $1 \begin{array}{lllllll}1 & 2 & 3 & 4 & 5 & \text { NA }\end{array}$

El instructor relacionó ideas con conocimientos previos.... $1 \begin{array}{llllll}1 & 2 & 3 & 4 & 5 & \mathrm{NA}\end{array}$

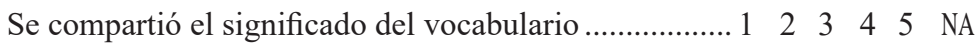

Contenido es modificado de acuerdo a los

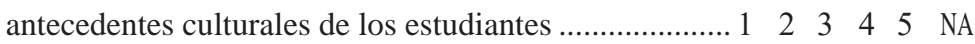

\section{ORGANIZACIÓN}

La introducción capturó la atención de los estudiantes...... $1 \begin{array}{llllll}1 & 2 & 3 & 4 & 5 & \text { NA }\end{array}$

La introducción indicó la organización de la lección .... $1 \begin{array}{lllllll}1 & 2 & 3 & 4 & 5 & \text { NA }\end{array}$

Las transiciones fueron efectivas (con resúmenes claros).. $1 \begin{array}{lllllll}1 & 2 & 3 & 4 & 5 & \text { NA }\end{array}$

La lección fue bien organizada ..................................... $1 \begin{array}{llllllllll} & 2 & 3 & 4 & 5 & \mathrm{NA}\end{array}$

Concluyó resumiendo ideas principales.......................... $1 \begin{array}{lllllll}1 & 2 & 3 & 4 & 5 & \mathrm{NA}\end{array}$

Conectó otras clases anteriores ...................................... $1 \begin{array}{llllllllll}1 & 2 & 3 & 4 & 5 & \mathrm{NA}\end{array}$

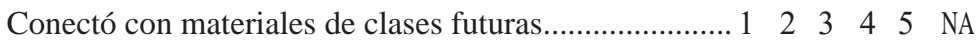

La organización ayudó a los estudiantes

multilingües y multiculturales 


\section{INTERACCIÓN}

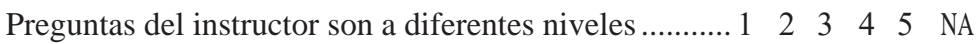

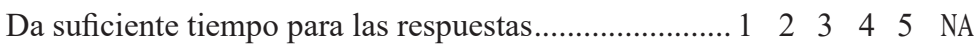

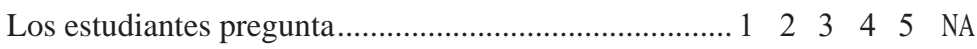

Comentarios del instructor sobre los trabajos

de los estudiantes los ayudan ........................................ $1 \begin{array}{lllllll} & 2 & 3 & 4 & 5 & \mathrm{NA}\end{array}$

Instructor incorporó las respuestas de los estudiantes ... $1 \begin{array}{llllll}1 & 2 & 3 & 4 & 5 & \mathrm{NA}\end{array}$

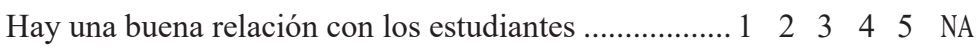

El profesor fue sensitivo/a con los

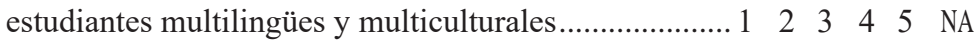

\section{VERBAL/NO VERBAL}

La explicación fue comprensible ................................... $1 \begin{array}{llllll} & 2 & 3 & 4 & 5 & \mathrm{NA}\end{array}$

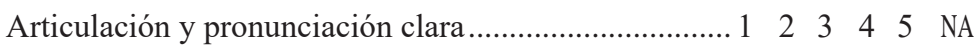

Ausencia de pausas verbalizadas (eh, ah, etc.) ............... $1 \begin{array}{lllllll}2 & 2 & 3 & 4 & 5 & \mathrm{NA}\end{array}$

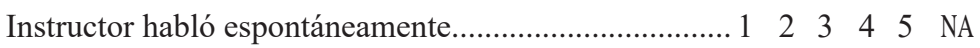

Acento no distrajo los estudiantes.................................. $1 \begin{array}{lllllll}1 & 2 & 3 & 4 & 5 & \mathrm{NA}\end{array}$

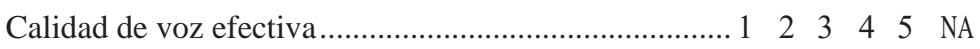

Volumen de la voz fue suficiente para ser oído............... $1 \begin{array}{llllll}2 & 2 & 3 & 4 & 5 & \text { NA }\end{array}$

La información fue compartida a velocidad apropiada.. $\begin{array}{lllllll}1 & 2 & 3 & 4 & 5 & \text { NA }\end{array}$

El movimiento del cuerpo y gestos fueron eficaces........ $1 \begin{array}{lllllll}1 & 2 & 3 & 4 & 5 & \text { NA }\end{array}$

Contacto visual con los estudiantes .............................. $1 \begin{array}{lllllll}1 & 2 & 3 & 4 & 5 & \mathrm{NA}\end{array}$

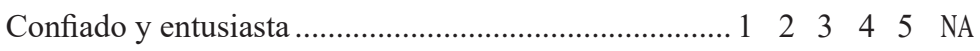

Uso del lenguaje verbal y no-verbal es entendido por todos los estudiantes con diversos antecedentes

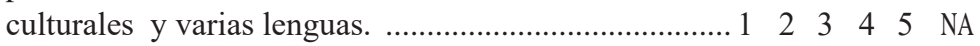

\section{USO DE LOS MEDIOS DE COMUNICACIÓN}

Contenido expresado fue claro y bien organizado ......... $1 \begin{array}{llllll}1 & 2 & 3 & 4 & 5 & \mathrm{NA}\end{array}$

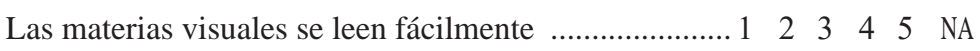

Instructor proporciona una guía/manual n...................... $1 \begin{array}{lllllll}1 & 2 & 3 & 4 & 5 & \mathrm{NA}\end{array}$

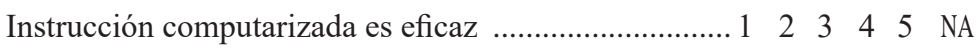

La tecnología promueve al aprendizaje de los

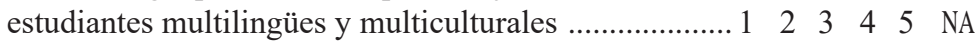




\section{SECCIÓN II}

Ajusta sus intervenciones/estrategias de lectura para estudiantes bilingües? $\square \mathrm{Si} \quad \square$ No

¿En caso afirmativo, podría darnos un ejemplo?

Si la respuesta es NO, sabe acerca de cómo el desarrollo del aprendizaje de lectura se ve afectada por el bilingüismo? $\square \mathrm{Si} \quad \square$ No

Sabe cómo creara un aula multicultural? $\square$ Si $\square$ No ¿En caso afirmativo, podría por favor darnos un ejemplo?

Sabe cómo usar investigación-acción para ajustar la instrucción en el aula? $\square$ Si $\square$ No

¿En caso afirmativo, podría por favor darnos un ejemplo? 


\section{Appendix 2}

\section{Classroom Observation Checklist}

Date of the Classroom Observation

Grade: Subject:

Gender: $\square \mathrm{M} \quad \square \mathrm{F} \quad$ How many year as a teacher:

\section{SECTION I}

Classroom Teaching Observation

Rating scale

$(1=$ very poor, $2=$ weak, $3=$ average, $4=\operatorname{good}, 5=$ excellent,

$\mathrm{NA}=$ not applicable)

\section{CONTENT}

Main ideas are clear and specific $\begin{array}{llllll}1 & 2 & 3 & 4 & 5 & \mathrm{NA}\end{array}$

Sufficient variety in supporting information $\begin{array}{lllllll}1 & 2 & 3 & 4 & 5 & \mathrm{NA}\end{array}$

Relevancy of main ideas was clear $\begin{array}{llllll}1 & 2 & 3 & 4 & 5 & \mathrm{NA}\end{array}$ Higher order thinking was required $\begin{array}{llllll}1 & 2 & 3 & 4 & 5 & \mathrm{NA}\end{array}$

Instructor related ideas to prior knowledge $\begin{array}{llllll}1 & 2 & 3 & 4 & 5 & \mathrm{NA}\end{array}$

Definitions were given for vocabulary. $\begin{array}{llllll}1 & 2 & 3 & 4 & 5 & \mathrm{NA}\end{array}$

Content modified according to student cultural background. $\begin{array}{llllll}1 & 2 & 3 & 4 & 5 & \mathrm{NA}\end{array}$

\section{ORGANIZATION}

Introduction captured attention $\begin{array}{llllll}1 & 2 & 3 & 4 & 5 & \mathrm{NA}\end{array}$

Introduction stated organization of lecture $\begin{array}{llllll}1 & 2 & 3 & 4 & 5 & \mathrm{NA}\end{array}$

Effective transitions (clear w/summaries) $\begin{array}{llllll}1 & 2 & 3 & 4 & 5 & \mathrm{NA}\end{array}$

Clear organizational plan $\begin{array}{llllll}1 & 2 & 3 & 4 & 5 & \mathrm{NA}\end{array}$

Concluded by summarizing main ideas $\begin{array}{llllll}1 & 2 & 3 & 4 & 5 & \mathrm{NA}\end{array}$

Reviewed by connecting to previous classes $\begin{array}{llllll}1 & 2 & 3 & 4 & 5 & \mathrm{NA}\end{array}$

Previewed by connecting to future classes $\begin{array}{llllll}1 & 2 & 3 & 4 & 5 & \mathrm{NA}\end{array}$

Organization aided in understanding for multilingual/multicultural students . 


\section{INTERACTION}

Instructor questions at different levels $\begin{array}{llllll}1 & 2 & 3 & 4 & 5 & \mathrm{NA}\end{array}$

Sufficient wait time $\begin{array}{lllll}2 & 3 & 4 & 5 & \mathrm{NA}\end{array}$

Students asked questions.

$\begin{array}{lllll}2 & 3 & 4 & 5 & \mathrm{NA}\end{array}$

Instructor feedback was informative $\begin{array}{lllll}2 & 3 & 4 & 5 & \mathrm{NA}\end{array}$

Instructor incorporated student responses $\begin{array}{lllll}2 & 3 & 4 & 5 & \mathrm{NA}\end{array}$

Good rapport with students $\begin{array}{lllll}2 & 3 & 4 & 5 & \mathrm{NA}\end{array}$

Instructor was sensitive to language minority status

$\begin{array}{lllll}2 & 3 & 4 & 5 & \mathrm{NA}\end{array}$

\section{VERBAL/NON-VERBAL}

Language was understandable $\begin{array}{llllll}1 & 2 & 3 & 4 & 5 & \mathrm{NA}\end{array}$

Articulation and pronunciation clear $\begin{array}{llllll}1 & 2 & 3 & 4 & 5 & \mathrm{NA}\end{array}$

Absence of verbalized pauses (er, ah, etc.) $\begin{array}{llllll}1 & 2 & 3 & 4 & 5 & \mathrm{NA}\end{array}$

Instructor spoke extemporaneously $\begin{array}{lllll}2 & 3 & 4 & 5 & \mathrm{NA}\end{array}$

Accent was not distracting $\begin{array}{lllll}2 & 3 & 4 & 5 & \mathrm{NA}\end{array}$

Effective voice quality $\begin{array}{llllll}1 & 2 & 3 & 4 & 5 & \mathrm{NA}\end{array}$

Volume sufficient to be heard $\begin{array}{llllll}1 & 2 & 3 & 4 & 5 & \mathrm{NA}\end{array}$

Rate of delivery was appropriate $\begin{array}{llllll}1 & 2 & 3 & 4 & 5 & \mathrm{NA}\end{array}$

Effective body movement and gestures $\begin{array}{lllll}2 & 3 & 4 & 5 & \mathrm{NA}\end{array}$

Eye contact with students $\begin{array}{lllll}2 & 3 & 4 & 5 & \mathrm{NA}\end{array}$

Confident \& enthusiastic $\begin{array}{llllll}1 & 2 & 3 & 4 & 5 & \mathrm{NA}\end{array}$ Use of language and non-verbal cues understood cross-culturally/linguistically $\begin{array}{llllll}1 & 2 & 3 & 4 & 5 & \mathrm{NA}\end{array}$ Language was appropriate to scaffold multilinguals understanding

\section{USE OF MEDIA}

Overheads/chalkboard content clear

$\&$ well organized $\begin{array}{llllll}1 & 2 & 3 & 4 & 5 & \mathrm{NA}\end{array}$

Visual aids can be easily read $\begin{array}{lllll}2 & 3 & 4 & 5 & \mathrm{NA}\end{array}$

Instructor provided an outline/handouts $\begin{array}{lllll}2 & 3 & 4 & 5 & \mathrm{NA}\end{array}$

Computerized instruction effective

Use of media enhanced learning for multilingual/multicultural learners 


\section{SECCIÓN II}

Do you adjust your reading strategies/interventions for bilingual students? $\square$ Yes $\square$ No

If yes, could you please provide an example?

If no, do you know about how reading development is impacted by bilingualism? $\square$ Yes $\square$ No

Do you create a multicultural classroom? $\square$ Yes $\square$ No

If yes, could you please provide an example?

Do you use action research to adjust instruction in the classroom?

$\square$ Yes $\square$ No

If yes, could you please provide an example? 


\section{Appendix 3:}

\section{Observations of Content Presentation}

\begin{tabular}{|c|c|c|c|c|c|c|c|c|c|c|c|c|}
\hline CONTENT & $\mathrm{MD}$ & $\mathrm{M}$ & & 5 & & 4 & & 3 & & 2 & & 1 \\
\hline $\begin{array}{l}\text { Q1. Main ideas are } \\
\text { clear and specific }\end{array}$ & 5 & 4.56 & 7 & $78 \%$ & 0 & $0 \%$ & 2 & $22 \%$ & 0 & $0 \%$ & 0 & $0 \%$ \\
\hline $\begin{array}{l}\text { Q2. Sufficient variety } \\
\text { in supporting information } \\
\text { Q3. Relevancy of main } \\
\text { ideas was clear }\end{array}$ & 5 & $\begin{array}{l}4.22 \\
4.78 \\
\end{array}$ & 7 & $\begin{array}{l}67 \% \\
78 \% \\
\end{array}$ & $\begin{array}{l}1 \\
2 \\
\end{array}$ & $\begin{array}{l}11 \% \\
22 \% \\
\end{array}$ & 0 & $\begin{array}{l}0 \% \\
0 \% \\
\end{array}$ & $\begin{array}{l}2 \\
0 \\
\end{array}$ & $\begin{array}{l}22 \% \\
0 \% \\
\end{array}$ & 0 & $\begin{array}{l}0 \% \\
0 \% \\
\end{array}$ \\
\hline $\begin{array}{l}\text { Q4. Higher order } \\
\text { thinking was required }\end{array}$ & 4 & 3.78 & 4 & $44 \%$ & 2 & $22 \%$ & 1 & $11 \%$ & 1 & $11 \%$ & 1 & $11 \%$ \\
\hline $\begin{array}{l}\text { Q5. Instructor related } \\
\text { ideas to prior knowledge } \\
\text { Q6. Definitions were } \\
\text { given for vocabulary }\end{array}$ & 4 & $\begin{array}{l}4.33 \\
4.33 \\
\end{array}$ & 4 & $\begin{array}{l}56 \% \\
44 \% \\
\end{array}$ & $\begin{array}{l}3 \\
4 \\
\end{array}$ & $\begin{array}{l}33 \% \\
44 \% \\
\end{array}$ & $\begin{array}{l}0 \\
1 \\
\end{array}$ & $\begin{array}{l}0 \% \\
11 \% \\
\end{array}$ & $\begin{array}{l}1 \\
0 \\
\end{array}$ & $\begin{array}{l}11 \% \\
0 \% \\
\end{array}$ & 0 & $\begin{array}{l}0 \% \\
0 \% \\
\end{array}$ \\
\hline $\begin{array}{l}\text { Q7. Content modified } \\
\text { according to student } \\
\text { cultural background }\end{array}$ & 3 & 2.78 & 3 & $33 \%$ & 0 & $0 \%$ & 2 & $22 \%$ & 0 & $0 \%$ & 4 & $44 \%$ \\
\hline
\end{tabular}

$1=$ very poor, $2=$ weak, $3=$ average, $4=$ good, $5=$ excellent

\section{Observations of Lesson Organization}

\begin{tabular}{|l|c|c|c|c|c|c|c|c|c|c|c|c|}
\hline $\begin{array}{l}\text { ORGANIZATION } \\
\begin{array}{l}\text { Q8. Introduction captured } \\
\text { students attention }\end{array}\end{array}$ & 5 & 4.56 & 7 & $78 \%$ & 0 & $0 \%$ & 2 & $22 \%$ & 0 & $0 \%$ & 0 & $0 \%$ \\
\hline $\begin{array}{l}\text { Q9. Introduction stated } \\
\text { organization of lecture }\end{array}$ & 5 & 4.11 & 5 & $56 \%$ & 2 & $22 \%$ & 0 & $0 \%$ & 2 & $22 \%$ & 0 & $0 \%$ \\
\hline $\begin{array}{l}\text { Q10. Effective transitions } \\
\text { (clear w/summaries) }\end{array}$ & 5 & 3.89 & 5 & $56 \%$ & 1 & $11 \%$ & 1 & $11 \%$ & 1 & $11 \%$ & 1 & $11 \%$ \\
\hline $\begin{array}{l}\text { Q11. Clear } \\
\text { organizational plan }\end{array}$ & 4 & 4.33 & 4 & $44 \%$ & 4 & $44 \%$ & 1 & $11 \%$ & 0 & $0 \%$ & 0 & $0 \%$ \\
\hline $\begin{array}{l}\text { Q12. Concluded by } \\
\text { summarizing main ideas }\end{array}$ & 5 & 4.33 & 6 & $67 \%$ & 1 & $11 \%$ & 1 & $11 \%$ & 1 & $11 \%$ & 0 & $0 \%$ \\
\hline $\begin{array}{l}\text { Q13. Reviewed by } \\
\text { connecting to previous } \\
\text { classes }\end{array}$ & 5 & 4.11 & 5 & $56 \%$ & 1 & $11 \%$ & 2 & $22 \%$ & 1 & $11 \%$ & 0 & $0 \%$ \\
\hline $\begin{array}{l}\text { Q14. Previewed by } \\
\text { connecting to future classes } \\
\text { QIN15. Organization aided in } \\
\text { understanding for multilingual/ } \\
\text { multicultural students }\end{array}$ & 4 & 3.22 & 4 & $44 \%$ & 1 & $11 \%$ & 0 & $0 \%$ & 1 & $11 \%$ & 3 & $33 \%$ \\
\hline \hline
\end{tabular}

$1=$ very poor, 2 = weak, 3 = average, $4=$ good, $5=$ excellent 


\section{Observations of Classroom Interactions}

\begin{tabular}{|l|c|c|c|c|c|c|c|c|c|c|c|c|}
\hline $\begin{array}{l}\text { INTERACTION } \\
\begin{array}{l}\text { Q16. Instructor questions } \\
\text { at different levels }\end{array}\end{array}$ & 5 & 4.33 & 6 & $67 \%$ & 1 & $11 \%$ & 1 & $11 \%$ & 1 & $11 \%$ & 0 & $0 \%$ \\
\hline $\begin{array}{l}\text { Q17. Sufficient wait time } \\
\text { for students' answers }\end{array}$ & 4 & 3.78 & 4 & $44 \%$ & 1 & $11 \%$ & 3 & $33 \%$ & 0 & $0 \%$ & 1 & $11 \%$ \\
\hline $\begin{array}{l}\text { Q18. Students } \\
\text { asked questions }\end{array}$ & 5 & 3.89 & 5 & $56 \%$ & 1 & $11 \%$ & 1 & $11 \%$ & 1 & $11 \%$ & 1 & $11 \%$ \\
\hline $\begin{array}{l}\text { Q19. Instructor feedback } \\
\text { was informative }\end{array}$ & 4 & 4.00 & 4 & $44 \%$ & 2 & $22 \%$ & 2 & $22 \%$ & 1 & $11 \%$ & 0 & $0 \%$ \\
\hline $\begin{array}{l}\text { Q20.Instructor incorporated } \\
\text { student responses }\end{array}$ & 5 & 4.44 & 6 & $67 \%$ & 1 & $11 \%$ & 2 & $22 \%$ & 0 & $0 \%$ & 0 & $0 \%$ \\
\hline $\begin{array}{l}\text { Q21. Good rapport } \\
\text { with students }\end{array}$ & 5 & 4.78 & 7 & $78 \%$ & 2 & $22 \%$ & 0 & $0 \%$ & 0 & $0 \%$ & 0 & $0 \%$ \\
\hline $\begin{array}{l}\text { Q22. Instructor was } \\
\text { sensitive to language } \\
\text { minority status }\end{array}$ & 4 & 3.44 & 4 & $44 \%$ & 1 & $11 \%$ & 1 & $11 \%$ & 1 & $11 \%$ & 2 & $22 \%$ \\
\hline
\end{tabular}

$1=$ very poor, $2=$ weak, $3=$ average, $4=$ good, $5=$ excellent

\section{Observations of Verbal / Non verbal Communication}

\begin{tabular}{|l|c|c|c|c|c|c|c|c|c|c|c|c|}
\hline $\begin{array}{l}\text { VERBAL/NON VERBAL } \\
\text { Q23. Language was } \\
\text { understandable }\end{array}$ & 5 & 4.44 & 5 & $56 \%$ & 3 & $33 \%$ & 1 & $11 \%$ & 0 & $0 \%$ & 0 & $0 \%$ \\
\hline $\begin{array}{l}\text { Q24. Articulation and } \\
\text { pronunciation clear }\end{array}$ & 5 & 4.67 & 7 & $78 \%$ & 1 & $11 \%$ & 1 & $11 \%$ & 0 & $0 \%$ & 0 & $0 \%$ \\
\hline $\begin{array}{l}\text { Q25. Absence of verbalized } \\
\text { pauses (er, ah, etc. }\end{array}$ & 4 & 4.00 & 4 & $44 \%$ & 2 & $22 \%$ & 2 & $22 \%$ & 1 & $11 \%$ & 0 & $0 \%$ \\
\hline $\begin{array}{l}\text { Q26. Instructor spoke } \\
\text { extemporaneously }\end{array}$ & 5 & 4.33 & 6 & $67 \%$ & 1 & $11 \%$ & 1 & $11 \%$ & 1 & $11 \%$ & 0 & $0 \%$ \\
\hline $\begin{array}{l}\text { Q27. Accent was } \\
\text { not distracting }\end{array}$ & 5 & 4.44 & 6 & $67 \%$ & 2 & $22 \%$ & 0 & $0 \%$ & 1 & $11 \%$ & 0 & $0 \%$ \\
\hline $\begin{array}{l}\text { Q28. Effective voice } \\
\text { quality }\end{array}$ & 5 & 4.44 & 5 & $56 \%$ & 3 & $33 \%$ & 1 & $11 \%$ & 0 & $0 \%$ & 0 & $0 \%$ \\
\hline $\begin{array}{l}\text { Q29. Volume sufficient } \\
\text { to be heard }\end{array}$ & 5 & 4.56 & 7 & $78 \%$ & 0 & $0 \%$ & 2 & $22 \%$ & 0 & $0 \%$ & 0 & $0 \%$ \\
\hline $\begin{array}{l}\text { Q30. Rate of delivery } \\
\text { was appropriate }\end{array}$ & 5 & 4.44 & 5 & $56 \%$ & 3 & $33 \%$ & 1 & $11 \%$ & 0 & $0 \%$ & 0 & $0 \%$ \\
\hline
\end{tabular}




\begin{tabular}{|l|l|l|l|l|l|l|l|l|l|l|l|l|}
\hline $\begin{array}{l}\text { Q31. Effective body } \\
\text { movement and gestures }\end{array}$ & 5 & 4.89 & 8 & $89 \%$ & 1 & $11 \%$ & 0 & $0 \%$ & 0 & $0 \%$ & 0 & $0 \%$ \\
\hline $\begin{array}{l}\text { Q32. Eye contact } \\
\text { with students }\end{array}$ & 5 & 4.78 & 7 & $78 \%$ & 2 & $22 \%$ & 0 & $0 \%$ & 0 & $0 \%$ & 0 & $0 \%$ \\
\hline $\begin{array}{l}\text { Q33. Confident } \\
\text { \& enthusiastic }\end{array}$ & 5 & 4.33 & 5 & $56 \%$ & 2 & $22 \%$ & 2 & $22 \%$ & 0 & $0 \%$ & 0 & $0 \%$ \\
\hline $\begin{array}{l}\text { Q34.Use of language and } \\
\text { non-verbal cues understood } \\
\text { cross-culturally/linguistically }\end{array}$ & 4 & 3.89 & 4 & $44 \%$ & 2 & $22 \%$ & 2 & $22 \%$ & 0 & $0 \%$ & 1 & $11 \%$ \\
\hline
\end{tabular}

$1=$ very poor, $2=$ weak, $3=$ average, $4=$ good, $5=$ excellent

\section{Observations of Media Use}

\begin{tabular}{|l|c|c|c|c|c|c|c|c|c|c|c|c|}
\hline $\begin{array}{l}\text { USE OF MEDIA } \\
\text { FOR COMMUNICATION }\end{array}$ & MD & M & & 5 & & 4 & & 3 & & 2 & & 1 \\
\hline $\begin{array}{l}\text { Q35. Overheads/ } \\
\text { chalkboard content } \\
\text { clear and well organized }\end{array}$ & 5 & 4.33 & 5 & $56 \%$ & 2 & $22 \%$ & 2 & $22 \%$ & 0 & $0 \%$ & 0 & $0 \%$ \\
\hline $\begin{array}{l}\text { Q36. Visual aids can } \\
\text { be easily read }\end{array}$ & 5 & 4.11 & 6 & $67 \%$ & 0 & $0 \%$ & 1 & $11 \%$ & 2 & $22 \%$ & 0 & $0 \%$ \\
\hline $\begin{array}{l}\text { Q37. Instructor provided } \\
\text { an outline/handouts }\end{array}$ & 5 & 4.33 & 5 & $56 \%$ & 2 & $22 \%$ & 2 & $22 \%$ & 0 & $0 \%$ & 0 & $0 \%$ \\
\hline $\begin{array}{l}\text { Q38. Computerized } \\
\text { instruction effective }\end{array}$ & 3 & 2.78 & 2 & $22 \%$ & 2 & $22 \%$ & 1 & $11 \%$ & 0 & $0 \%$ & 4 & $44 \%$ \\
\hline $\begin{array}{l}\text { Q39. Use of media enhanced } \\
\text { learning for multilingual } \\
\text { Imulticultural learners }\end{array}$ & 3 & 3.00 & 2 & $22 \%$ & 2 & $22 \%$ & 1 & $11 \%$ & 2 & $22 \%$ & 2 & $22 \%$ \\
\hline
\end{tabular}

$1=$ very poor, $2=$ weak, $3=$ average, $4=$ good, $5=$ excellent 